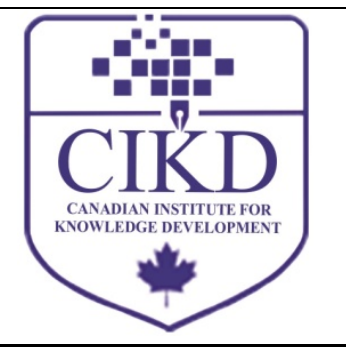

\title{
The Impact of Transformational Leadership and Social Interaction on Organizational Performance in the Viewpoint of Knowledge Management: An Empirical Study in Banking Sector of Pakistan.
}

\author{
Raza Hussain Lashari ${ }^{1 *}$, Aiza Hussain Rana ${ }^{2}$ \\ ${ }^{1}$ Lahore Garrison University, Pakistan \\ ${ }^{2}$ Lahore Garrison University, Pakistan (A Project of Pakistan Army)
}

\section{Keywords:}

Transformational Leadership (TL), Social Interaction (SI), Knowledge Management (KM),

Organizational

Performance $(O P)$,

Banking Sector of Pakistan

\section{Received}

28 May 2018

Received in revised form

01 November 2018

Accepted

15 November 2018

Correspondence:

razahussain10312@gmail.com

\section{ABSTRACT}

This research examines the impact of transformational leadership (TL) and social interaction (SI) on organizational performance (OP) in the perspective of knowledge management (KM) within Pakistan's banking sector. In developing countries, knowledge management (KM) is highly practiced but in Pakistan it is a new concept and at the initial stages of its implementation. The situation of Pakistan's banking sector is better than other services sectors. Therefore, Pakistan's banking sector is opted as population of the study. Using the simple random sampling technique, 350 questionnaires were distributed in different bank's branches. The questionnaires were filled by two officer's rank of employee, i.e., top level managers and middle level managers. Totally, 270 questionnaires were fully completed and used for final analysis. The overall response rate was $77 \%$. Different statistical techniques were applied on the collected data, i.e., Reliability analysis, Pearson's correlation, Regression analysis and Sobel test. The results indicated that there is a positive relationship among transformational leadership, social interaction, knowledge management, and organizational performance. Furthermore, knowledge management acted as partially mediator between transformational leadership, social interaction and organizational performance. Additionally, current research provides guidelines to the management of banking sector of developing countries specially Pakistan that how transformational leadership, social interaction and knowledge management can improve the organizational performance. 
Knowledge is the key source of competitive edge for organizations (Chen, 2004; Matusik \& Hill, 1998; Spender \& Grant, 1996). Its management is also considered an important source of competitive advantage that can positively influence organizations' overall performance (Drucker, 1993; Dutta, 1997; Nonaka \& Takeuchi, 1995). Organizations are now moving towards knowledge-based economy rather than industrial economy (Danish, Asghar, \& Asghar, 2014). To achieve superior and desired outcomes, effective organizations continuously manage and absorb knowledge assets into their functioning activities (Droge, Claycomb, \& Germain, 2003; Teece, 1998). Knowledge is a main resource of any organization which is embedded in human's mind (Malhotra, 1997). According to Baker, Baker, Thorne and Dutnell (1997), knowledge is a set of information, abilities, expertise and practices that are used by the individuals to resolve different issues of the organization. The approach in which organizations create, use, apply, share and store knowledge is known as knowledge management (Probst, Buchel, \& Raub, 1998). Thus, the objective of current research is to check the impact of transformational leadership and social interaction on organizational performance in the viewpoint of knowledge management in banking sector of Pakistan. The research explores the impact of knowledge management in Pakistan's banking sector because this sector is playing crucial role in country's economy (Shah, Jhatial, \& Ghumro, 2012b). According to SBP, (2015) the growth rate of Pakistan's banking sector is $16.8 \%$ which is better than all other service sectors. Knowledge management is vital to banking sector as it is for any other kind of organization (Li, 2012).

In the present study, researchers explore the relationship between transformational leadership (TL) and knowledge management (KM). There are many styles of leadership but TL enhances level of KM, improves the process of KM and implements KM in any organization (Noruzi, Majazi Dalfard, Azhdari, Nazari-Shirkouhi, \& Rezazadeh, 2013). Furthermore, transformational leadership style has positive impact on knowledge management (Bryant, 2003; Crawford, 2005). For knowledge management, social interaction is considered important medium for organization's members (Bartol \& Srivastava, 2002; Levin \& Cross, 2004; Singh, 2005). Social interaction refers to the extent to which organizational members interact with each other in terms of trust, communication, and coordination (Chen \& Huang, 2007).

Does an organization achieve its objective or not, it can be measured with an indicator which an is organizational performance (Hamon, 2003; Venkatraman \& Ramanujam, 1986). Organizational performance (OP) is a critical concept because to date there is no any generally agreeable rang among researchers who can justify it (Carton, 2004). There are number of studies which have witnessed a direct/positive relationship between an organizational performance (OP) and efficient and effective application of KM (Gold Malhotra, \& Segars, 2001; Hasan \& Al-Hawari, 2003; Lee \& Lee, 2007; Schultz \& Jobe, 2001). Knowledge management is an emerging issue in the field of management. Therefore, the basic purpose of the present study is to develop well-organized and effective knowledge management framework especially in the banking sector of Pakistan.

\section{Problem Statement}

Knowledge management is widely practiced in developing and developed countries which are in various stages of its application (Asian Productivity Organization, APO, 2005). According to 
Akhavan, Jafari, and Fathian (2005), many organizations fail due to lack of proper knowledge management system and they further quoted the failure rate as $50 \%$ but this rate of failure can be increased if organizations do not introduce effective and efficient knowledge management system. A study conducted among the top 40 management consultant organizations of US indicated that more than $60 \%$ of them identified knowledge management as an important success factor for their businesses (Ofek \& Saravay, 2001). According to Arif, (2013), knowledge management has $87 \%$ significant effect on organizational performance. A research conducted by Nitin Nohria and colleagues at Harvard Business School found, for example, that on average, leader contributes $14 \%$ approximately on the performance of an organization (as cited in Creating, 2003). The growth of banking sector heavily depends on how well leaders understand the objective of organization, need of the market, how effectively they share as well as apply knowledge to the employee of an organization and how successfully the employees deliver this knowledge to their customers as well (Piri \& Asefzadeh, 2006; Prodromos \& Vraimaki, 2009). Moreover, social interaction phenomena, i.e., trust, communication and coordination improves knowledge management's structure in modern banking sector (Chatzoglou \& Vraimaki, 2009).

In Pakistan, knowledge management is a new concept and it is at the initial stages of its implementation (Tayyab, 2009). It is evident from the vision 2030, Pakistan will make knowledge-based economy by promoting innovative culture and knowledge sharing society for efficient and effective utilization of the knowledge resources (Government of Pakistan, GoP, 2007).

\section{Rationale of the Study}

Many organizations believe that effective knowledge management is only way to control their core competencies and achieve competitive edge (Tayyab, 2009). Many studies explain the causal relationship between knowledge management (KM) and organizational performance (OP) that KM builds a competitive advantage which is directly linked to organizational performance (Chadha \& Kapoor, 2010; Wang Hult, Ketchen, \& Ahmed, 2009; Zack, Mckeen, $\&$ Singh, 2009). The effective Management of Knowledge may have an important role in successful performance of Pakistani Banks (Ahmed, Fiaz, \& Shoaib, 2015). The present study not only covers above mentioned gap but also provides the guidance to improve the knowledge management activities for their better performance within the banking sector of Pakistan.

\section{Knowledge Management (KM)}

$\mathrm{KM}$ is a way to improve procedures and practices, develop and enhance employee abilities, improve the learning curve related with new employees or new tasks and customer service as well (Roman, 2004). KM is a process that control the individual and mutual knowledge within firm to avail competitive benefit (Carlsson, 2003). KM is a planned action which ensure that to cope with rapidly changing environment; organizations have sufficient knowledge to manage different situations (Alvesson \& Karreman, 2001). In this study, researcher focus on knowledge sharing and knowledge application which are dimensions of KM. 
Knowledge Sharing (KS)

The process in which individuals and groups deliver knowledge to solve difficult problems within short period of time is called knowledge sharing (Cross \& Sproull, 2004). Without sharing, it is difficult for knowledge to be delivered to individuals or team (Quink, 2008).

\section{Knowledge Application (KA)}

The competitive advantage of the organization depends upon knowledge application as compared to knowledge itself because it is main feature of "knowledge-based theory" of the organization (Alavi \& Leidner, 2001; Grant, 1996b).

\section{Transformational Leadership (TL)}

According to Burns, (1978), TL is a process in which leaders and followers help each other to develop higher level of motivation and morale. There are many styles of leadership but TL enhances level of KM, improves the process of $\mathrm{KM}$ and implements $\mathrm{KM}$ in any organization (Noruzi, et al., 2013). There are four dimensions of TL known as "the Four I's" including Idealized Influence or Charismatic leadership, Inspirational Motivation, Intellectual Stimulation, Individualized Consideration (Bass \& Avolio, 1994). But in current study, the researcher selected one more dimension that is risk acceptance (Xiaoxia \& Jing, 2006).

Idealized Influence/Charisma (II): By using charismatic or idealized influence transformational leaders impress their subordinates. Moreover, such type of leaders, in the time of difficulty listen and solve problems of their workers. These leaders have proficiencies and enthusiasm to solve the problems of employees (Bass \& Riggio, 2006).

Inspirational Motivation (IM): Inspirational motivation is a process in which leaders motivate and encourage employees by providing them meaningful and challenging task. For envision of optimistic future, leaders encourage their employees and promote team spirit, enthusiasm, and optimism among themselves (Bass, Avolio, Jung, \& Berson, 2003).

Intellectual Stimulation (IS): In this behavior, leaders encourage employees to think in creative, innovative and effective way. They involve them in decision making process and also find solution of problems that influence their social, political, environmental, economic wellbeing (Nwagbara, 2010).

Individualized consideration (IC): In this trait of TL, leaders act as a mentor and provide special attention to each employee's need. Leaders individually guide and support employees to find their potential skills and act accordingly (Bass \& Riggio, 2006).

Risk Acceptance (RA): Risk acceptance is a characteristics of a leader that is now included in transformational leadership's dimensions because transformational leaders accept risk positively and view risk as opportunity rather than threat. In this characteristic, leaders show their risk acceptance attitude when they face technological and organizational problems (Xiaoxia \& Jing, 2006).

\section{Social Interaction (SI)}

The extent in which organizational members interact with each other in terms of communication, trust and coordination is called social interaction (Chen \& Huang, 2007). According to Chen \& Huang, (2007) there are three dimensions of SI: Trust, Communication, 
and Coordination. Trust is a mutual understanding between employees and leaders for sharing and applying knowledge within the organization (Bartol \& Srivastava, 2002). Common understanding and trusty behavior among individuals and groups allow organizations to promote knowledge sharing and knowledge application behaviors within the organization with proficiently (Bartol \& Srivastava, 2002). According to Hoegl, Parboteeah, and Munson (2003), communication is a process of transforming any kind of knowledge to organization's members. The degree in which individuals and groups feel that their organizations well integrated and organized is called coordination (Janz, Wehterbe, Colquitt, \& Noe, 1997). Coordinative behaviors among organizational departments enhance the sharing and application of required knowledge inside the firms (Tsai, 2002; Janz et al., 1997).

\section{Organizational Performance $(O P)$}

Organizational performance (OP) is generally measured by using two indicators, i.e., efficiency and effectiveness, where efficiency refers to financial viability such as profitability (Stewart, 2010). According to Daft (2000) and Ricardo and Wade (2001), organizational performance means an appropriate use of resources in an effective and efficient manner. This concerns how an organization is able to achieve its goals. As Organization Performance has been considered in depth now but still remains debatable subject among organizational scholars (Barney, 1997). However, it is generally measured in two dimensions, i.e., financial and non-financial. The financial dimension means profitability, return on investment, return on asset (ROA), return on sale (ROS), return on equity (ROE), stock price, export growth, sales growth, revenue growth, operational efficiency, market share and organizational success (Gimenez, 2000; Stewart, 2010; Thomas \& Ramaswamy, 1996). The Non-financial performance, on the other hand, measures OP in terms of organizational commitment, job satisfaction, employee turnover, innovativeness, customer satisfaction, quality, and flexibility in resource utilization (Kaplan \& Norton, 2001).

Organizational performance can be assessed using either objective or subjective mode (Dess \& Robinson, 1984). The objective approach refers to the financial data provided by the organization; whereas, the subjective measurement calls upon the perception of the employees (Croteau \& Bergeron, 2001). Current research focuses on subjective approach by using the structured questionnaire and collects primary data from the respondents. According to Croteau and Bergeron (2001) proposed two dimensions to measure organizational performance, i.e., sales growth and probability on the basis of concept presented by Venkatraman and Ramanujam, 1986). This research focuses on the concept of Croteau and Bergeron (2001) and uses the two dimensional construct of organizational performance, i.e., sales growth and probability.

The surplus of revenue over expenses or the ability for a company to make a profit consistently, is critical to the persistence of an organization (Drucker, 1954). Clearly, profitability was the primary organizational performance dimension which is used as a dependent variable. Of 138 articles, $70 \%$ included a profitability variable as at least one of the dependent organizational performance measures. Growth was the second most common performance dimension used to measure overall organizational performance. Growth has long been considered a critical and distinct component of organizational financial performance 
(Drucker, 1954; Venkatraman \& Ramanujam, 1987). Capon, Farley, and Hoenig (1990) found, using a meta-analysis of performance-related studies, that sales growth rate was a generallyaccepted performance indicator. They found that sales growth is positively and robustly associated with other measures of firm financial performance.

\section{Method}

Hypotheses

Gelard, Boroumand, and Mohammadi (2014) proved that transformational leadership has positive impact on knowledge management. Accordingly, current research proposes the hypothesis 1 as following:

$\mathbf{H}_{1}$ : Transformational leadership plays an important role in knowledge management.

Social interaction has a strong positive impact on knowledge management (Chen \& Huang 2007). On the basis of this fact current research propose the hypothesis 2 as following:

$\mathbf{H}_{2}$ : Social interaction puts strong influence on knowledge management.

Knowledge management positively influences organizational performance (Ho, 2008). In the light of literature, current research proposes the hypothesis 3 as following:

$\mathbf{H}_{3}$ : Knowledge management puts strong influences on organizational performance.

From the best of researchers' knowledge, the relationship between transformational leadership, social interaction with organization performance by using knowledge management as mediator has not checked in pervious literature. Therefore, current study proposes the following hypotheses:

$\mathbf{H}_{4}$ : Knowledge management plays a mediating role between transformational leadership and organizational performance.

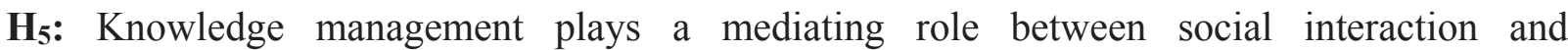
organizational performance.

Figure 1 shows the theoretical framework of the study.

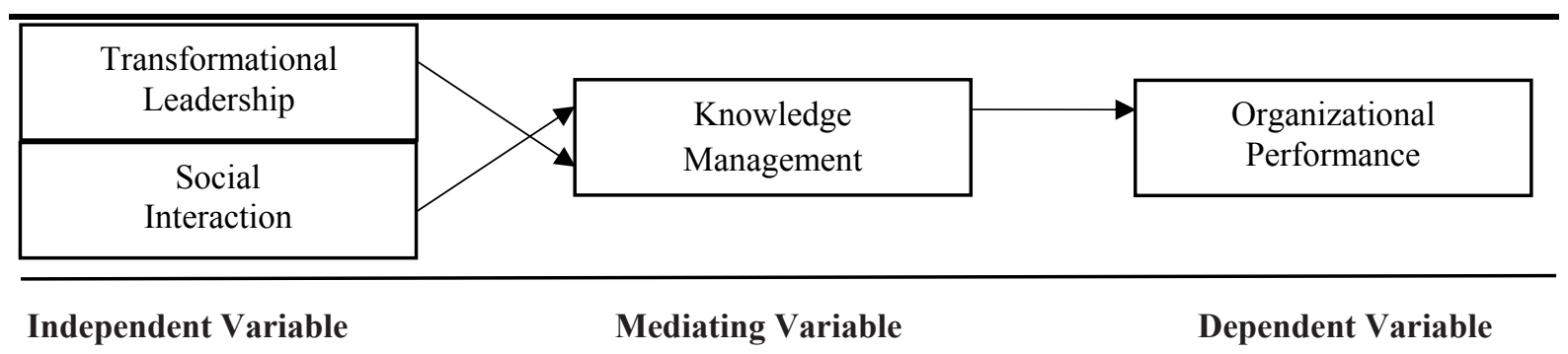

Figure 1. Theoretical framework

\section{Instrument}

This study examines the relationship between transformational leadership, social interaction, knowledge management and organizational performance. Already established instruments are adopted in this study. The items and dimensions of transformational leadership are taken from the instruments modified by Xiaoxia and Jing (2006). Based on the work of Sivadas and Dwyer (2000), three dimensions of SI including communication, trust, coordination and its items were adopted. Based on the work of Gold et al. (2001) and Lin and Lee (2005), the researchers selected two dimensions of knowledge management, i.e., Knowledge sharing, knowledge 
application and its items. The concepts were measured by using seven point Likert scale from strongly disagree to strongly agree. According to the work of Venkatraman (1989), the researchers took the eight items of organizational performance. For measuring this concept, 7 point Likert scale from very dissatisfactory to very satisfactory was used. Thirty-five statements were finalized to measure the organizational performance.

\section{Population}

The present study focuses on the employees of banking sector of Pakistan as population. Due to shortage of time and capital, we selected the banks in Lahore as a sample for data collection. According to Israel, (1992) a good sample size, 200-500, is needed for simple and multiple regression which might be performed for more rigorous state impact evaluations. Therefore, using simple random sampling, 350 questionnaires were distributed among different branches of banks in Lahore, Pakistan. Of 350 questionnaires, 100 and 250 questionnaires were distributed to public bank's employees and to the employees of private banks, respectively. In data collection process, 270 questionnaires were received back and used for data analysis. Data was collected from top level managers and middle level managers. Overall, response rate of return was $77 \%$.

\section{Results}

\section{Validity and Reliability}

Validity is an important component of research and is concerned with whether the outcomes are actually about and what they appear (Saunders, Lewis, \& Thornhill, 2007). Before measuring the behavior of individuals by different questions, the questions must be relevant, well formulated and supported to the research. In this study, there are 35 statements which measure the attitudes and behavior of individuals. However, the questionnaire employed in this study was already used and showed high extent of validity. This study is based upon 270 employees of banks. The top level and middle level employees are involved in this research. The overall Cronbach's alpha is .91. George and Mallery (2003) provided more detailed classes of reliability values (i.e., $>0.9$ "Excellent", $>0.8$ "Good", $>0.7$ "Acceptable", $>0.6$ "Questionable", $>0.5$ "Poor", while $<0.5$ "Unacceptable"). Therefore, the value of Cronbach's alpha is good enough for this study.

\section{Correlation Analysis}

In order to examine the relationship among transformational leadership, social interaction, knowledge management and organizational performance, a bivariate correlation analysis was used. Table 1 shows the results of correlation analysis.

Table 1

Pearson's Correlation Analysis

\begin{tabular}{|c|c|c|c|c|}
\hline Variables & TL & SI & KM & $\mathrm{OP}$ \\
\hline Transformational leadership (TL) & 1 & & & \\
\hline Social interaction (SI) & $.603 * *$ & 1 & & \\
\hline $\begin{array}{l}\text { Knowledge management (KM) } \\
\text { Organizational Performance (OP) }\end{array}$ & $\begin{array}{l}.578^{* *} \\
.645^{* *}\end{array}$ & $\begin{array}{l}.721^{* *} \\
939^{* *}\end{array}$ & 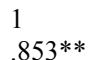 & 1 \\
\hline
\end{tabular}

**Correlation is significant at the 0.01 level (2-tailed). 
Table 1 shows relationship between variables of current research. The value range from $.578^{* *}$ to $.939^{* *}$, and these are positively associated with each other. That is between the range of 0 to +1 . There is a highly significant relationship between TL and OP which is $.645^{* *}$, where ** shows the highly significance between two variables. Similarly, SI has a very highly significant relation with the OP which is $.939^{* *}$ and there is a highly significant relationship between $\mathrm{KM}$ and OP which is .853**.

\section{Regression Analysis}

Regression analysis is a very powerful tool in the field of statistical analysis because it predicts the value of one variable, given the value of another variable, when those variables are related to each other. Regression analysis also provides estimates of values of the dependent variables from the values of independent variables. All hypotheses were tested according to Baron and Kenny's (1986) standards of testing mediation. Following abbreviations are used for the variables of the study: transformational leadership (TL), knowledge management (KM), organizational performance (OP) Standard error (SE).

$\boldsymbol{H}_{1}$ : Transformational leadership plays an important role in knowledge management.

Table 2

Regression Analysis

\begin{tabular}{lcccc}
\hline & $\beta$ & Std. Error & $t$ & $p$ \\
\hline Constant & 1.44 & .34 & 4.18 & .000 \\
$\mathrm{TL}$ & .76 & .06 & 11.58 & .000 \\
$\mathrm{R}^{2}$ & .33 & & & .000 \\
$\mathrm{~F}$ & 134.28 & & \\
\hline ***Significant at the 0.01 level. **Significant at the 0.05 level. * Significant at the 0.10 level & \\
\multicolumn{2}{l}{ Dependent Variable: Knowledge management (KM); Independent Variable (Predictor): Transformational leadership (TL) }
\end{tabular}

As shown in Table 2, value of $\mathrm{R}^{2}$ shows the level of effect of the independent variables on dependent variables. The value of $\mathrm{R}^{2}$ is .33 . The value of $\mathrm{R}^{2}$ should be greater than .25 . The Value of $\mathrm{F}$ defines the level of relationship between dependent variables and independent variables. Greater value of $F$ denotes that there is a strong relation between these variables. The value of $\mathrm{F}$ in results is 134.28 and its significance value is .000. This shows that there is a strong relationship among dependent variables and independent variables. The value of $t$ should be non-zero and Table 2 indicates that t-value is non-zero. For the relationship of TL and $\mathrm{KM}$, the value of $\beta=.76$ indicates that one unit change in transformational leadership may result in $77.0 \%$ change in knowledge management. The value of $p$ describes the real extent of the relationship. When the value of $p$ is less than $.10, .01$ or .05 , then the hypotheses are accepted. In this relationship, i.e., transformational leadership and knowledge management, the value of $\mathrm{p}$ for the relationship is .000 which is less than .01 . This means that hypothesis regarding transformational leadership and knowledge management is accepted.

$\boldsymbol{H}_{2}$ : Social interaction puts strong influence on knowledge management.

Table 3

Regression Analysis

\begin{tabular}{lcccc}
\hline & $\beta$ & Std. Error & $t$ & $p$ \\
\hline Constant & 1.12 & .25 & 4.41 & .000 \\
$\mathrm{SI}$ & .83 & .04 & 17.02 & .000 \\
$\mathrm{R}^{2}$ & .52 & & .000 \\
$\mathrm{~F}$ & 289.79 & & \\
\hline ***Significant at the 0.01 level. **Significant at the 0.05 level. * Significant at the 0.10 level & &
\end{tabular}

***Significant at the 0.01 level. **Significant at the 0.05 level. * Significant at the 0.10 level

Dependent Variable: Knowledge management (KM); Independent Variable (Predictor): Social interaction (SI) 
As presented in Table 3, the value of $\mathrm{R}^{2}$ is .52 . The value of $\mathrm{F}$ is 289.79 and its significance value is .000 . The value of $t$ is non-zero. Among the relationship of SI and KM, the value of $\beta=.83$ shows that one unit change in social interaction may result in $83.2 \%$ change in knowledge management within banking sector of Pakistan. The hypothesis regarding social interaction and knowledge management is accepted.

$\boldsymbol{H}_{3}$ : Knowledge management puts strong influences on organizational performance.

Table 4

Regression Analysis

\begin{tabular}{lcccc}
\hline & $\beta$ & Std. Error & $t$ & $p$ \\
\hline Constant & 1.22 & .15 & 8.09 & .000 \\
$\mathrm{KM}$ & .73 & .02 & 26.71 & .000 \\
$\mathrm{R}^{2}$ & .72 & & .000 \\
$\mathrm{~F}$ & 713.83 & & \\
\hline$* * *$ Significant at the 0.01 level. **Significant at the 0.05 level. * Significant at the 0.10 level & &
\end{tabular}

(he 0.05 level. * Significant at the 0.10 level

Dependent Variable: Organizational Performance (OP); Independent Variable (Predictor): Knowledge Management (KM

As indicated in Table 4, the value of $\mathrm{R}^{2}$ is .72 . The value of $F$ is 713.83 and its significance value is .000 . The value of $t$ is non-zero. In the relationship of $\mathrm{KM}$ and $\mathrm{OP}$, the value of $\beta=.73$ indicates that one unit change in knowledge management may result in $74.0 \%$ change in organizational performance within banking sector of Pakistan. The hypothesis regarding knowledge management and organizational performance is accepted.

$\boldsymbol{H}_{4}$ : Knowledge management plays mediating role between transformational leadership and organizational performance.

As presented in Table 5, for the mediation analysis, the predictor (transformational leadership) is related to the outcome (organizational performance) which is Step 1. The standardized regression coefficient $(\beta=.76)$ associated with the transformational leadership on organizational performance is significant $(p<.05)$. Therefore, Path $\mathrm{c}$ is significant, and thus the condition of mediation in Step 1 is met. Figure 1 shows the mediator effect of KM on TL and OP.

Table 5

Testing Mediator Effect of KM on TL (IV) and OP (DV)

\begin{tabular}{|c|c|c|c|c|c|c|}
\hline Testing Steps of Mediation & $B$ & $S E$ & $F$ & $R^{2}$ & Decision & $B$ \\
\hline \multicolumn{7}{|l|}{ Step 1 (Path c) } \\
\hline \multicolumn{7}{|l|}{ Outcome: OP } \\
\hline Predictor: TL & .73 & .05 & 190.76 & .41 & $.000<.05$ & .73 \\
\hline \multicolumn{7}{|l|}{ Step 2 (Path a) } \\
\hline Outcome: KM & & & & & & \\
\hline Predictor: TL & .76 & .06 & 134.29 & .33 & $.000<.05$ & .76 \\
\hline $\begin{array}{l}\text { Step } 3 \text { (Paths b and c' } \\
\text { Outcome: OP }\end{array}$ & & & 713.83 & .72 & $.000<.05$ & \\
\hline Mediator: KM (Path b) & .62 & .03 & & & $.000<.05$ & .62 \\
\hline Predictor: TL (Path c') & .26 & .04 & 426.99 & .76 & $.000<.05$ & .26 \\
\hline
\end{tabular}




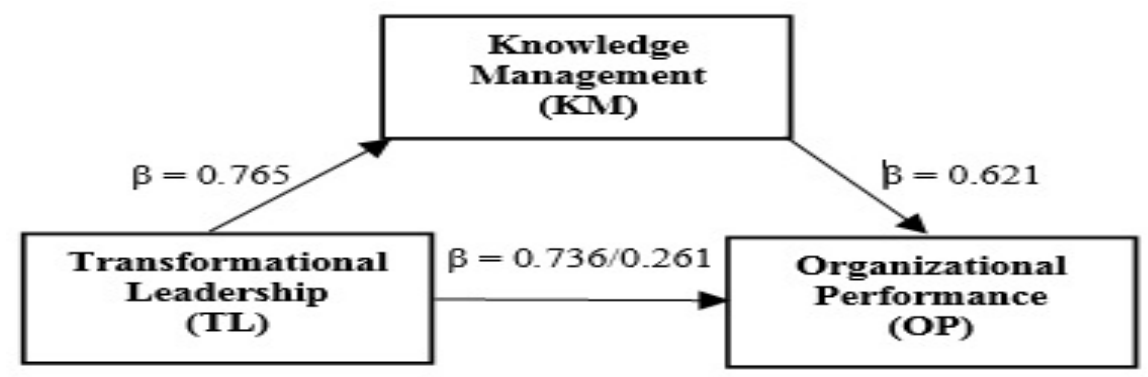

Figure 2. Mediator effect of KM on TL and OP

As displayed in Figure 1, the regression coefficient $(\beta=.765)$ is significant, $p<.05$ and thus the condition of Step 2 is met (significant Path a). This shows that transformational leadership is related to knowledge management (the hypothesized mediator).

To test whether knowledge management is related to organizational performance; organizational performance regressed simultaneously on both transformational leadership and the knowledge management variables (Step 3). The coefficient concerning the relationship between knowledge management and organizational performance (controlling for transformational leadership), is significant ( $\beta=.621, p<.05)$. Thus, the condition for Step 3 is met (significant Path $b$ ). The third regression analysis also provided an estimate of Path $\mathrm{c}^{\prime}$, the relation between transformational leadership and organizational performance, controlling for knowledge management. When path $\mathrm{c}^{\prime}$ is zero, i.e., the independent variable becomes insignificant, then there can be a complete mediation. Nevertheless, Path $c^{\prime}$ is $(\beta=.261)$ also significant $(p<.05)$, though it is smaller than Path $\mathrm{c}$ which is .736. After controlling for knowledge management, the effect of transformational leadership appeared to be significant and smaller, i.e., from $\beta=.736$ to $\beta=.261$ and hence reduced by $.736-.261=.475$ which is supported partial mediation. To check the significance of indirect effect, Soble test was applied which eventually determined the significance of partial mediation. The results of Soble test indicated that indirect effect (.475) is statistically significant $(\mathrm{z}=10.66, p<.05)$. Hence, it is established that knowledge management acts as a partially mediator between transformational leadership and organizational performance and this hypothesis is accepted. It is important to know the amount of mediation. It is calculated from the standard of Shrout and Bolger (2002) which is $a b / c(.475 / .736=.64)$ and it is obtained from unstandardized coefficients. Thus, about $64 \%$ of the total effect of transformational leadership on organizational performance is mediated by knowledge management.

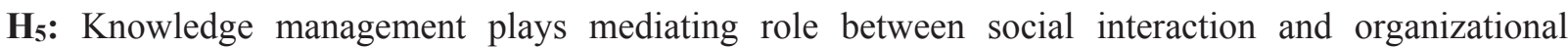
performance.

For the mediation analysis as presented in Table 6 and Figure 3, it is established that the predictor (social interaction) is related to the outcome (organizational performance) which is the Step 1. The standardized regression coefficient $(\beta=.934)$ associated with the social interaction on organizational performance is significant $(p<.05)$. Therefore, Path $\mathrm{c}$ is significant, and thus condition of mediation in Step 1 is met. 
Table 6

Testing Mediator Effect of KM on SI (IV) And OP (DV)

\begin{tabular}{|c|c|c|c|c|c|}
\hline Testing Steps of Mediation & $B$ & $S E$ & $F$ & $R^{2}$ & Decision \\
\hline \multicolumn{6}{|l|}{ Step 1 (Path c) } \\
\hline Outcome: OP & .934 & .021 & 198.42 & .881 & $.000<.05$ \\
\hline \multicolumn{6}{|l|}{ Predictor: SI } \\
\hline \multicolumn{6}{|l|}{ Step 2 (Path a) } \\
\hline Outcome: KM & .832 & .049 & 289.79 & .520 & $.000<.05$ \\
\hline \multicolumn{6}{|l|}{ Predictor: SI } \\
\hline Step 3 (Paths b and c' & & & 713.83 & .727 & $.000<.05$ \\
\hline \multicolumn{6}{|l|}{ Outcome: OP } \\
\hline Mediator: KM (Path b) & .316 & .018 & & & $.000<.05$ \\
\hline Predictor: SI (Path c') & .671 & .020 & & & $.000<.05$ \\
\hline
\end{tabular}

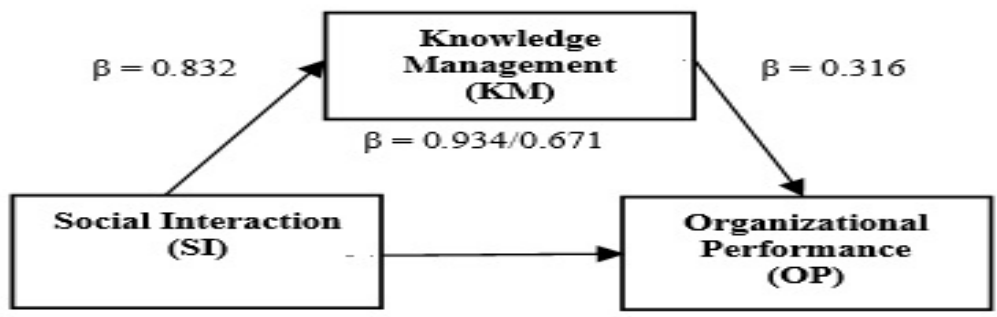

Figure 3. Mediator Effect of KM on SI and OP

As displayed in Table 6 and Figure 3, the regression coefficient $(\beta=.832)$ is significant, $p<$ .05 and thus the condition of Step 2 is met (significant Path a). This shows that the social interaction is related to knowledge management (the hypothesized mediator).

To test whether knowledge management is related to organizational performance, the organizational performance regressed simultaneously on both social interaction and the knowledge management variables (Step 3). The coefficient, the relation between knowledge management and organizational performance (controlling for social interaction), is also significant, $\beta=.316, p<.05$. Thus, the condition for Step 3 is met (significant Path $b$ ). The third regression analysis is also provided an estimate of Path $\mathrm{c}^{\prime}$, the relation between social interaction and organizational performance, controlling for knowledge management. When path $\mathrm{c}^{\prime}$ is zero, i.e., the independent variable becomes insignificant, then there can be a complete mediation. Nevertheless, Path $\mathrm{c}^{\prime}$ is $(\beta=.671)$ also significant $(p<.05)$, though it is smaller than Path $\mathrm{c}$ which is .934. After controlling for knowledge management, the effect of social interaction appeared to be significant and smaller, i.e., from $\beta=.934$ to $\beta=.671$ and hence reduced by $.934-.671=.263$ which is supported partial mediation. To check the significance of indirect effect, Soble test was performed which is eventually determined the significance of partial mediation. The results of Soble test indicated that indirect effect (.263) is statistically significant, $z=14.40, p<.05$. Therefore, it is established that knowledge management acts as partially mediator between social interaction and organizational performance and hypothesis is accepted. By using the standard of Shrout and Bolger (2002) the value of mediation was calculated which is $a b / c, .263 / .934=.28$ and it is obtained from unstandardized coefficients. Thus, about $28 \%$ of the total effect of social interaction on organizational performance is mediated by knowledge management. 


\section{Discussion}

This research examines the role of knowledge management between transformational leadership, social interaction and organizational performance. The results revealed a positive association between the transformational leadership, social interaction, knowledge management and organizational performance. The prior studies and their results proposed the similar positive relationship between TL and KM (Gelard et al., 2014). Moreover, the earlier studies and their results also revealed the similar effect of SI with KM (Chen \& Hung, 2007). In addition, the results of different studies have indicated a positive relationship between KM and organizational performance (Gold et al., 2001; Hasan \& Al-Hawari, 2003; Lee \& Lee, 2007; Schultz \& Jobe, 2001). Thus, above discussion clarifies that current research is also in compliance with the preceding studies. Furthermore, the results of the regression analysis indicate that in general if organization adopts transformational leadership style, the knowledge will be easily managed among organizational members and then the volume of organizational performance will be increased.

As the results of the present study indicated, knowledge management partially mediates between transformational leadership and organizational performance. In addition, if an organization promotes social interaction behavior among individuals, the management of knowledge will be improved among members and then the levels of organizational performance will be increased. Therefore, knowledge management plays a mediating role in the relationship between social interaction and organizational performance. It can be concluded that if the banks of developing countries especially in Pakistan, adopt transformational leadership style and enhance the social interaction behavior within organization, then knowledge will be properly managed and ultimately the performance of the organization will be increased.

\section{Managerial Contribution and Limitation}

From a practical point of view, this study suggests that managers should be aware of the importance of knowledge management in the link of transformational leadership, social interaction and organizational performance. The empirical results indicate that transformational leadership and social interaction are crucial for knowledge management and ultimately for organizational performance.

This study has some limitations. Due to the cost and time restraint, the target population focused on only banks of Lahore. The target population of current research is only banking sector but other sectors such as textile sector, education sector and telecommunication sector remained unexplored. This is a cross-sectional study; the data were collected from respondents at specific point of time.

For future research, the population and sample size of the current research can be increased in order to get better and generalized results. The same research can also be conducted in other organizations, e.g., industrial sector, telecommunications, hospitality sectors, educational institutions to check the generalizability of the results. A longitudinal study on banking sector of Lahore can also reveal other aspects of the present study. Further research can be conducted to determine the factors that influencing the adoption of knowledge management in the banking sector of Pakistan. 


\section{References}

Ahmed, S., Fiaz, M., \& Shoaib, M. (2015). Impact of knowledge management practices on organizational performance: An empirical study of banking sector in Pakistan. FWU Journal of Social Sciences, Winter, 9(2), 147 -167.

Akhavan, P., Jafari, M., \& Fathian, M. (2005). Exploring failure-factors of implementing knowledge management systems in organizations. Journal of Knowledge Management Practice, 6, 1-8.

Alavi, M., \& Leidner, D. E. (2001). Review: Knowledge management and knowledge management systems: conceptual foundations and research issues. MIS Quarterly, 25(1), 107-136.

Alvesson, M., \& Kaerreman, D. (2001). Odd couple: Making sense of the curious concept of knowledge management. The Journal of Management Studies, 38(7), 995-1018.

Arif, M. (2013). Impact of knowledge management performance with mediating system on organizational effect of innovation (Unpublished master's thresis). Department of management \& social sciences Mohammad Ali Jinnah University, Islamabad.

Asian Productivity Organization (2005). State of knowledge management. A study meeting on the measurement of Knowledge Management in Asia, December 6-9, 2005, Yogyakarta, Indonesia.

Baker, M., Baker, M., Thorne, J., \& Dutnell, M. (1997). Leveraging human capital. Journal of Knowledge Management, 1(1), 63-74.

Barney, J. B. (1997). Gaining and sustaining competitive advantage. Reading, MA: Addison, Wesley.

Baron, R. M., \& Kenny, D. A. (1986). The moderator-mediator variable distinction in social psychological research: Conceptual, strategic, and statistical considerations. Journal of personality and social psychology, 51, 11-73.

Bartol, K. M., \& Srivastava, A. (2002). Encouraging knowledge sharing: The role of organizational reward systems. Journal of Leadership and Organizational Studies, 9(1), 64-76.

Bass, B. M., \& Avolio, B. J. (1994). Improving organizational effectiveness through transformational leadership. California: USA7: Sage.

Bass, B.M., \& Riggio, R.E. (2006). Transformational leadership (2nd ed.). Mahwah, NJ: Lawrence Erlbaum Associates Publishers.

Bass, B. M., Avolio, B.J., Jung, D. I., \& Berson, Y. (2003). Predicting unit performance by assessing transformational and transactional leadership. The Journal of Applied Psychology, 88, 207-218.

Bryant, S. E. (2003). The role of transformational and transactional leadership in creating, sharing, and exploiting knowledge. Journal of Leadership \& Organizational Studies, 94, 32-44.

Burns, J. M. (1978). Leadership. NewYork: Harper and Row.

Capon, N., Farley, J. U., \& Hoenig, S. (1990). Determinants of financial performance: A metaanalysis. Management Science, 36(10), 1143-1159.

Carlsson, S. A. (2003). Knowledge managing and knowledge management systems in inter-organizational networks. Knowledge and Process Management, 10(3), 194-206.

Carton, B. R. (2004). Measuring organizational performance: An exploratory study (Unpublished Doctoral dissertation). University of Georgia, Athens.

Chadha, S. K., \& Kapoor, D. (2010). A study on knowledge management practices of auto component manufacturing companies in Ludhiana city the 70 IUP. Journal of Knowledge Management, 8(1,2), 68 -76.

Chatzoglou, P. D., \& Vraimaki, E. (2009). Knowledge-sharing behavior of Bank Employees in Greece. Business Process Management Journal, 15(2), 245-266.

Chen, C. (2004). The effects of knowledge attribute, alliance characteristics, and absorptive capacity on knowledge transfer performance. R\&D Management, 34(3), 311-321.

Chen, C. J., \& Huang J. W. (2007). How organizational climate and structure affect knowledge management-the social interaction perspective. International Journal of Information management, 27, 104-118.

Crawford, C. B. (2005). Effects of transformational leadership and organizational position on knowledge management. Journal of Knowledge Management, 9, 6-16.

Creating Leaders. (2003). The economist [supplement: a survey of corporate leadership], 7-11. October 25.

Cross, R., \& Sproull, L. (2004). More than an answer: Information relationships for actionable knowledge. Organization Science, 15(4), 446-462.

Croteau, A. M., \& Bergeron, F. (2001). An information technology trilogy: Business strategy, technology deployment and organizational performance. Journal of Strategic Information System 10, 77-99. 
Daft, R. L. (2000). Organization theory and design. (7th ed.). United States of America: South-Western College Publishing, Thomson Learning.

Danish, R. Q., Asghar, A., \& Asghar, S. (2014). Factors of knowledge management in banking sector of Pakistan. Journal of Management Information System and E-commerce, 1, 41-49.

Dess, G. G., \& Robinson, R. B. (1984). Measuring organizational performance in the absence of objective measures: the case of the privately held firm and conglomerate business unit. Strategic management Journal 5, 265-273.

Droge, C., Claycomb, C., \& Germain, R. (2003). Does knowledge mediate the effect of context on performance? Some initial evidence. Decision Sciences, 34(3), 541-568.

Drucker, P. (1993). Managing for results, reprint ed. London: Collins.

Drucker, P. (1954). The Practice of management. New York: Harper and Row.

Dutta, S. (1997). Strategies for implementing knowledge-based systems. IEEE Transactions on Engineering Management, 44(1), 79-90.

Gelard, P., Boroumand, Z., \& Mohammadi, A. (2014). Relationship between transformational leadership and knowledge management. International Journal of Information Science and Management, 12(2), 67-82.

George, D., \& Mallery, P. (2003). SPSS for Windows step by step: A simple guide and reference. 11.0 update. 4th ed. Boston: Allyn \& Bacon.

Gimenez, F. A. P. (2000). The benefits of a coherent strategy for innovation and corporate change: A study applying miles and snow's model in the context of small firms. Strategy and Innovation in SMEs, 9(4), 235-244.

Gold, A. H., Malhotra, A., \& Segars, A. H. (2001). Knowledge management: An organizational capabilities perspective. Journal of Management Information System, 18(1), 185-214.

Government of Pakistan GoP. (2007), Vision 2030. Working Paper, Islamabad: Planning commission.

Grant, R. M. (1996b). Toward a knowledge-based theory of the firm. Strategic Management Journal, Winter Special Issue, 17, $109-122$.

Hamon, T. T. (2003). Organizational effectiveness as explained by social structure in a faith-based business network organization (Unpublished doctoral dissertation). Regent University, Virginia Beach, VA.

Hasan, H., \& Al-Hawari, M. (2003). Managing styles and performance: A knowledge space framework. Journal of Knowledge Management, 7(4), 15-28.

Hoegl, M., Parboteeah, K. P., \& Munson, C. L. (2003). Team-level antecedents of individuals' knowledge networks. Decision Sciences, 34(4), 741-770.

Israel, G. D. (1992). Determining sample size. Florida: University of Florida Cooperative Extension Service, Institute of Food and Agriculture Sciences, EDIS.

Janz, B. D., Wehterbe, J. C., Colquitt, J. A., \& Noe, R. A. (1997). Knowledge worker team effectiveness: The role of autonomy interdependence, team development, and contextual support variables. Personnel Psychology, 50(4), 877-904.

Kaplan, R. S., \& Norton, D. P. (2001). The strategy-focused organization: how balanced scorecard companies thrive in the new business environment. Boston, MA: Harvard Business School Press.

Lee, Y. C., \& Lee, S. K. (2007). Capability, processes, and performance of knowledge management: A structural approach. Human Factors and Ergonomics in Manufacturing, 17(1), 21-41.

Levin, D. Z., \& Cross, R. (2004). The strength of weak ties you can trust: The mediating role of trust in effective knowledge transfer. Management Science, 50(11), 1477-1490.

Lin, H. F., \& Lee, G. G. (2005). Impact of organizational learning and knowledge management factors on e-business adoption. Management Decision, 43(2), 171-188.

Malhotra, Y. (1997). Knowledge management in inquiring organizations. Proceedings of the 3rd Americas Conference on Information Systems Philosophy of Information Systems Mini-track), Indianapolis (PP. 293-295).

Matusik, S. F., \& Hill, C. W. L. (1998). The utilization of contingent work, knowledge creation, and competitive advantage. Academy of Management Review, 23(4), 680-697.

Nonaka, I., \& H. Takeuchi (1995). The knowledge-creating company: How Japanese companies create the dynamics of innovation. New York: Oxford University Press.

Noruzi, A., Majazi Dalfard, V. Azhdari, B., Nazari-Shirkouhi, S., \& Rezazadeh, A. (2013). Relations between transformational leadership, organizational learning, knowledge management, organizational innovation, and organizational performance: An empirical investigation of manufacturing firms. The International Journal of Advanced Manufacturing Technology, 64 (5,8), 1073-1085. 
Nwagbara, U. (2010). Towards a paradigm shift in the Niger delta: Transformational leadership change in the era of post amnesty deal. Journal of Sustainable Development in Africa, 12(3), 387-401.

Ofek, E. \& Saravay, M. (2001). Leveraging the customer base: creating competitive advantage through knowledge management. Management Science, 47(11), 11414-1156.

Piri, Z., \& S. Asefzadeh (2006). How KM can be applied to Healthcare Organizations? The Journal of Qazvin University of Medical Sciences, 10(38), 124-132.

Probst, G., Buchel, B., \& Raub, S. (1998). Knowledge as strategic resource, understanding, Managing and Measuring Knowledge. London /New Delhi: Sage.

Prodromos, D. C., \& Vraimaki, H. (2009). Knowledge-sharing behavior of bank employees in Greece. Journal Business Process Management, 15(2), 245-266.

Quink, U. (2008). An exploration of knowledge management and intellectual capital in a nonprofit organization context (Unpublished master's thesis). Queensland University of Technology (QUT), Queensland.

Ricardo, R., \& Wade, D. (2001). Corporate performance management: How to build a better organization through measurement driven strategies alignment. United Kingdom: Butterworth Heinemann.

Roman-Velazquez, J. A. (2004). An empirical study of knowledge management processes at individual, group and organizational levels. Decision Sciences, 34(2), 255-261.

Saunders, M., Lewis, P., \& Thornhill, A. (2007). Research methods for business. Third Edition. England: Prentice Hall.

Schultz, T., \& Jobe, L. A. (2001). Codification and tacitness as knowledge management strategies, an empirical exploration. Journal of High Technology Management Research, 12(1), 139-165.

Shah, A. A., Jhatial, A. A., \& Ghumro, I. A. (2012b). A narrative description of banking sector in pakistan. Interdisciplinary Journal of Contemporary Research In Business, 4(1), 638-656.

Shrout, P. E., \& Bolger, N. (2002). Mediation in experimental and non-experimental studies: New procedures and recommendations. Psychological methods, 7, 422-445.

Singh, J. (2005). Collaborative networks as determinants of knowledge diffusion patterns. Management Science, 51(5), $756-$ 770 .

Sivadas, E., \& Dwyer, F. R. (2000). An examination of organizational factors influencing new product success in internal and alliance-based processes. Journal of Marketing, 64(1), 31-50.

Spender, J. C., \& Grant, R. (1996). Knowledge and the firm: Overview. Strategic Management Journal, 17, 5-9.

Stewart, D. (2010). Growing the corporate culture. Retrieved from https://www.wachovia.com/foundation/v/index.jsp?vgnextoid=ab411 f07760aa110VgnVCM1000004b0d1872 RCRD\&vgnextfmt.

Tayyab, B. B. (2009). Organizational culture and knowledge management processes in the Pakistani Corporate Sectors (Unpublished doctoral dissertation). Department of Administrative Sciences Quaid-i-Azam University, Islamabad Pakistan.

Teece, D. J. (1998). Capturing value from knowledge assets: The new economy, markets for know-how, and intangible assets. California Management Review, 40(3), 55-79.

Thomas, Anisya S., \& Ramaswamy, K. (1996). Matching managers to strategy: Further tests of the miles and snow typology. British Journal of Management, 7, 247-261.

Tsai, W. (2002). Social structure of "coopetition" within a multiunit organization: Coordination, competition, and intraorganizational knowledge sharing. Organization Science, 13(2), 179-190.

Venkatraman, N. (1989). The concept of fit in strategy research: Toward verbal and statistical correspondence. Academy of Management Review, 14(3), 423-444.

Venkatraman, N., \& Ramanujam, V. (1986). Measurement of business economic performance: An examination of method convergence. Journal of Management Development, 13(1),109-122.

Venkatraman, N., \& Ramanujam, V. (1987). Measurement of business economic performance: An examination of method convergence. Journal of Management, 13(1), 109-122.

Wang, L., Hult, G. Ketchen Jr M., D. J., \& Ahmed, P. K. (2009). Knowledge management orientation, market orientation, and firm performance: an integration and empirical examination. Journal of Strategic Marketing, 17(2), 99-122.

Xiaoxia, P., \& Jing, W., (2006). Transformational leadership vs transactional leadership: The influence of gender and culture on leadership styles of SMEs in China and Sweden (Unpublished master's thesis). Kristianstad University, Sweden

Zack, M., Mckeen, J., \& Singh, S. (2009). Knowledge management and organizational performance: an exploratory analysis. Journal of knowledge management, 13(6), 392-409. 